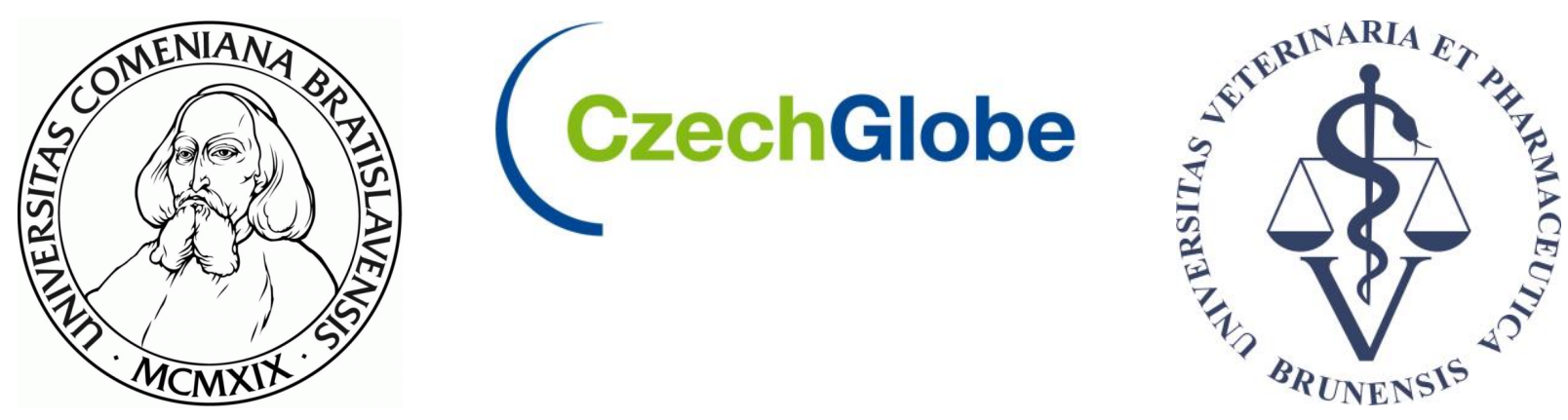

\title{
Preparation and Photosynthesis-Inhibiting Activity of 1-[(2-Nitrophenyl)carbamoyl]naphthalen-2-yl Alkylcarbamates
}

\section{Tomas Gonec $^{1, *}$, Josef Stranik ${ }^{1}$, Matus Pesko ${ }^{2}$, Jiri Kos ${ }^{1}$, Michal Oravec ${ }^{3}$, Katarina Kralova ${ }^{4}$, Josef Jampilek ${ }^{5} *$}

${ }^{1}$ Department of Chemical Drugs, Faculty of Pharmacy, University of Veterinary and Pharmaceutical Sciences, Palackeho 1, 61242 Brno, Czech Republic; e-mail: t.gonec@seznam.cz

2 Department of Environmental Ecology, Faculty of Natural Sciences, Comenius University, Mlynska dolina Ch-2, 84215 Bratislava, Slovakia

${ }^{3}$ Global Change Research Institute CAS, Belidla 986/4a, 60300 Brno, Czech Republic

${ }^{4}$ Institute of Chemistry, Faculty of Natural Sciences, Comenius University, Mlynska dolina Ch-2, 84215 Bratislava, Slovakia

${ }^{5}$ Department of Pharmaceutical Chemistry, Faculty of Pharmacy, Comenius University, Odbojarov 10, 83232 Bratislava, Slovakia; e-mail: josef.jampilek@ gmail.com

* Authors to whom correspondence should be addressed.

\begin{abstract}
In this study, a series of eight 1-[(2-nitrophenyl)carbamoyl]naphthalen-2-yl alkylcarbamates was prepared and characterized. The discussed compounds were prepared by microwave-assisted and conventional synthesis. The compounds were tested for their activity related to inhibition of photosynthetic electron transport (PET) in spinach (Spinacia oleracea L.) chloroplasts. The PET-inhibiting activity of the compounds was relatively low; the corresponding $\mathrm{IC}_{50}$ values ranged from 0.233 to $0.487 \mathrm{mmol} / \mathrm{L}$ and the highest activity within the series of compounds was observed for 1-[(2-nitrophenyl)carbamoyl]naphthalen-2-yl pentylcarbamate. The compounds were found to inhibit PET in photosystem II.
\end{abstract}

Keywords: Alkylcarbamates; Hydroxynaphthalene-carboxamides; PET inhibition; Spinach chloroplasts; Structure-activity relationships.

\section{INTRODUCTION}

The presence of an amide or carbamate $(-\mathrm{CONH}-,-\mathrm{OCONH}-)$ group with hydrophobic residue in its close vicinity is characteristic not only of a number of clinically used drugs [1] but also of many applied pesticides [2]. These moieties are important functional groups that are able, due to their electron properties, to interact and bind with a number of 
enzymes/receptors and, by means of these target sites, affect the biological response. The properties of the amide and the carbamate moieties can be easily modified by various substitutions $[3,4]$. These groups are characteristic of a number of herbicides acting as inhibitors of photosynthetic electron transport (PET) in photosystem (PS) II [5-21]. Moreover, in the middle of the 1970's it was found that salicylanilides belong to effective uncoupling agents of oxidative phosphorylation [22-24], and acceleration of the deactivation reactions of water splitting enzyme system $\mathrm{Y}$ by 3-tert-butyl-5-chloro- $N$-(2-chloro4-nitrophenyl)-2-hydroxybenzamide was observed [23]. Substituted salicylanilides or their bioisosteres inhibited PET [14-21,25-28] and reduced chlorophyll content in green alga, Chlorella vulgaris [25-27]. It is important to note that in addition to the above-mentioned herbicidal activity, the wide spectrum of biological effects of salicylanilides includes, for example, antibacterial, antimycobacterial, antifungal and anthelmintic activity; however, their mechanism of action is still under investigation [29 and refs. therein].

In the context of the above-mentioned facts, 1-[(2-nitrophenyl)-carbamoyl]naphthalen-2-yl alkylcarbamates were prepared [30] and some of them tested were for their photosynthesisinhibiting activity - the inhibition of photosynthetic electron transport (PET) in spinach chloroplasts (Spinacia oleracea L.).

\section{RESULTS AND DISCUSSION}

All the studied compounds were prepared according to Scheme 1 [30]. In the first step, $N$-(2-nitrophenyl)-2-hydroxynaphthalene-1-carboxamide (1) was synthesized by the microwave-assisted method [18]. In the second step, a modified method using triethylamine for activation of the phenolic group was used [16]. The addition of activated compound $\mathbf{1}$ to appropriate alkyl isocyanates yielded a series of eight 1-[(2-nitrophenyl)carbamoyl]naphthalen-2-yl alkylcarbamates 2-9.

Scheme 1. Synthesis of 1-[(2-nitrophenyl)carbamoyl]naphthalen-2-yl alkylcarbamates 2-9 [30]: (a) $\mathrm{PCl}_{3}$, chlorobenzene, $\mathrm{MW}$; (b) TEA, acetonitrile, ambient temperature.<smiles>[R]NC(=O)Oc1ccc2ccccc2c1C(=O)Nc1ccccc1[N+](=O)[O-]</smiles>

R: $\mathbf{2}=$ ethyl; $\mathbf{3}=$ propyl; $\mathbf{4}=$ isopropyl; $\mathbf{5}=$ butyl; $\mathbf{6}=$ pentyl; $\mathbf{7}=$ hexyl; $\mathbf{8}=$ heptyl; $\mathbf{9}=$ octyl

All the predicted molecular descriptors (lipophilicity, hydrophobic distributive parameters, molar volumes and surface) were calculated using the ACD/Percepta ver. 2012 program (Advanced Chemistry Development, Toronto, ON, Canada), see Table 1. The lipophilicity of compounds 2-9, expressed as $\log P$ values, ranged from 3.58 (compound 2, $\mathrm{R}=\mathrm{C}_{2} \mathrm{H}_{5}$ ) to 7.22 (compound 9, $\mathrm{R}=\mathrm{C}_{8} \mathrm{H}_{17}$ ). Logically, lipophilicity increases with lengthening of the alkyl tail. Isopropyl showed lower lipophilicity value than propyl. For individual substituents - alkyl chains of the discussed compounds - also hydrophobic properties expressed as distributive parameters $\pi$ were predicted; they ranged from 0.99 to 4.18. Bulkiness (i.e. tail length/branching) of individual substituents expressed as molar volume $\mathrm{MV}\left[\mathrm{cm}^{-3}\right]$ and surface activity expressed as surface tension ST [dyne/cm] of the discussed carbamates were determined as other parameters that could influence PET-inhibiting activity. 
Table 1. Structure of 1-[(2-nitrophenyl)carbamoyl]naphthalen-2-yl alkylcarbamates 2-9, calculated values of $\log P$ and surface tension (ST [dyne/cm]) of compounds and hydrophobic distributive parameters $\pi$ and molar volume $\mathrm{MV}\left[\mathrm{cm}^{-3}\right]$ of $\mathrm{R}$ substituents (calculated using ACD/Percepta ver. 2012) and $\mathrm{IC}_{50}[\mathrm{mmol} / \mathrm{L}]$ values related to PET inhibition in spinach chloroplasts of tested compounds in comparison with 3-(3,4-dichlorophenyl)-1,1-dimethylurea (DCMU).

\begin{tabular}{|c|c|c|c|c|c|c|}
\hline Comp. & $\mathbf{R}$ & $\log P$ & $\pi$ & $\mathrm{MV}\left[\mathrm{cm}^{3}\right]$ & $\begin{array}{c}\mathrm{ST} \\
\text { [dyne/cm] } \\
\end{array}$ & $\begin{array}{l}\text { PET inhibition } \\
\text { IC }_{50}[\mathrm{mmol} / \mathrm{L}] \\
\end{array}$ \\
\hline 2 & $\mathrm{C}_{2} \mathrm{H}_{5}$ & 3.58 & 0.99 & 47.29 & 61.24 & 0.450 \\
\hline 3 & $\mathrm{C}_{3} \mathrm{H}_{7}$ & 3.96 & 1.52 & 63.80 & 59.35 & 0.365 \\
\hline 4 & $\mathrm{CH}\left(\mathrm{CH}_{3}\right)_{2}$ & 3.80 & 1.34 & 64.18 & 58.30 & 0.664 \\
\hline 5 & $\mathrm{C}_{4} \mathrm{H}_{9}$ & 4.32 & 2.05 & 80.31 & 57.71 & 0.274 \\
\hline 6 & $\mathrm{C}_{5} \mathrm{H}_{11}$ & 5.15 & 2.58 & 96.81 & 56.26 & 0.233 \\
\hline 7 & $\mathrm{C}_{6} \mathrm{H}_{13}$ & 5.71 & 3.12 & 113.32 & 54.97 & 0.283 \\
\hline 8 & $\mathrm{C}_{7} \mathrm{H}_{15}$ & 6.81 & 3.65 & 129.83 & 53.82 & 0.352 \\
\hline 9 & $\mathrm{C}_{8} \mathrm{H}_{17}$ & 7.22 & 4.18 & 146.33 & 52.79 & 0.487 \\
\hline DCMU & - & - & - & - & - & 0.002 \\
\hline
\end{tabular}

The PET-inhibiting activity was expressed by negative logarithm of $\mathrm{IC}_{50}$ value (compound concentration in $\mathrm{mol} / \mathrm{L}$ causing 50\% inhibition of PET). The evaluated 1-[(2-nitrophenyl)carbamoyl]naphthalen-2-yl alkylcarbamates showed relatively low activity related to PET inhibition in spinach (Spinacia oleracea $\mathrm{L}$.) chloroplasts with $\mathrm{IC}_{50}$ values ranging from 0.233 to $0.487 \mathrm{mmol} / \mathrm{L}$, see Table 1. 1-[(2-Nitrophenyl)carbamoyl]naphthalen-2-yl pentylcarbamate (6) had the highest PET-inhibiting activity $\left(\mathrm{IC}_{50}=0.233 \mathrm{mmol} / \mathrm{L}\right)$ within the investigated series.

The dependences of the PET-inhibiting activity $\log \left(1 / \mathrm{IC}_{50}[\mathrm{~mol} / \mathrm{L}]\right)$ of compounds 2-9 in spinach chloroplasts on lipophilicity (expressed as $\log P$ ), hydrophobicity (expressed as distributive parameter $\pi$ ) and bulkiness expressed as molar volume MV of the alkyl tails as well as on surface activity expressed as surface tension ST of compounds are illustrated in Figures 1A-1D. Bilinear dependences of activity on individual descriptors can be observed in all Figures. The PET-inhibiting activity within the series linearly increased with the increase of $\log P$ values (as lipophilicity of the whole structure including intramolecular interactions, correlation coefficient $\mathrm{r}=0.9541, \mathrm{n}=4$, Fig. 1A), distributive parameter (influence of substituent $\mathrm{R}$ hydrophobicity, $\mathrm{r}=0.9949, \mathrm{n}=4$, Fig. 1B), molar volume (influence of substituent $\mathrm{R}$ bulkiness, $\mathrm{r}=0.9949, \mathrm{n}=4$, Fig. 1C) and with increasing surface tension (i.e. with a decrease of surface activity, $r=0.9851, n=4$, Fig. 1D) up to pentyl derivative 6. After this optimum, activity linearly decreased with the subsequent increase of lipophilicity $(\mathrm{r}=-0.9666, \mathrm{n}=4$, Fig. 1A), distributive parameter $(\mathrm{r}=-0.9919, \mathrm{n}=4$, Fig. 1B), molar volume $(\mathrm{r}=-0.9923, \mathrm{n}=4$, Fig. 1C) and surface tension (i.e. with a surface activity decrease, $r=-0.9956, n=4$, Fig. 1D). A better correlation coefficient estimated for the dependence of $\log \left(1 / \mathrm{IC}_{50}\right)$ on distributive parameter $\pi$ characterizing the hydrophobicity of $\mathrm{R}$ substituent compared to that of $\log \left(1 / \mathrm{IC}_{50}\right)$ on $\log P$ characterizing 
the lipophilicity of the whole molecule indicates that the inhibitory activity is dominantly affected by R substituent causing perturbation of thylakoid membranes. On the other hand, in general limited PET-inhibiting activity of the compounds can be caused by possible interactions of amide and carbamate groups (responsible also for interactions with photosynthetic apparatus) with the spatially close $\mathrm{NO}_{2}$ moiety in the ortho position of anilide ring [16-19,31].

An increase of PET-inhibiting activity with the prolongation of the alkyl tail estimated for compounds $2,3,5,6$ is connected with the fact that a longer alkyl chain can be incorporated in the thylakoid membrane to a greater extent and subsequently causes membrane damage. This biological activity is connected with the surface activity of these compounds (they can be considered as non-ionic surfactants) and with the alkyl tail length (molar volume), which is again reflected in lipophilicity. Nevertheless, besides the above-mentioned physicochemical parameters, also the appropriate concentration of the compound at the site of action in the photosynthetic apparatus is important for PET-inhibiting activity. Consequently, a compound having poor water solubility cannot pass through the hydrophilic regions of the thylakoid membrane to reach the site of action, which results in a significant decrease of inhibitory activity. The solubility of hexyl derivative $\mathbf{7}$ and especially derivatives $\mathbf{8}$ and $\mathbf{9}$ with longer alkyl chains was significantly lower than that of pentyl derivative $\mathbf{6}$, which resulted in a notable activity decrease. From the aspect of PET-inhibiting activity, the lipophilicity optimum can be found for $\mathrm{C}_{5}$, see Fig. 1. With the further elongation of the alkyl chain (hydrophobic part) to octyl, so called 'cut-off' effect, i.e. the loss of biological activity with the increasing lipophilicity of the compounds usually observed for amphiphilic compounds was manifested [5,28,32-34].

Figure 1. Dependence of PET-inhibiting activity $\log \left(1 / \mathrm{IC}_{50}[\mathrm{~mol} / \mathrm{L}]\right)$ of compounds $2-9$ in spinach chloroplasts on lipophilicity of compounds expressed as $\log P(\mathbf{A})$, hydrophobic distributive parameters $\pi$ of R substituents (B), bulkiness of R substituents expressed as molar volume MV $\left[\mathrm{cm}^{-3}\right]$ of alkyl tail $(\mathbf{C})$ and surface tension $(\mathrm{ST}$ [dyne/cm]) (D) of compounds.
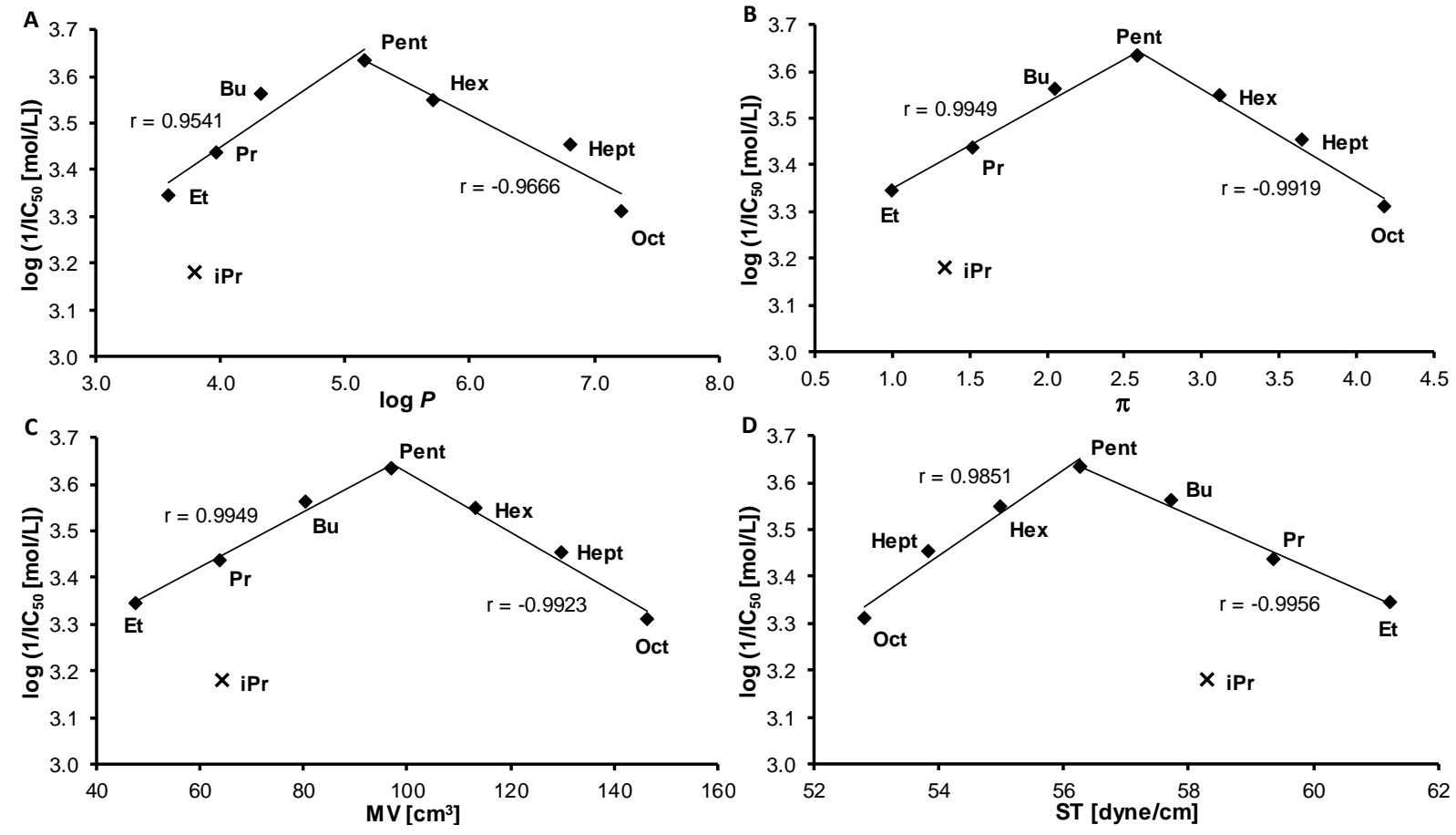

The application of 2,5-diphenylcarbazide (DPC, artificial electron donor) that supplies electrons in the site of $Z^{\bullet} / D^{\bullet}$ intermediate, i.e. tyrosine radicals $\operatorname{Tyr}_{Z}$ and $\operatorname{Tyr}_{D}$ (or their surroundings) that are situated in $\mathrm{D}_{1}$ and $\mathrm{D}_{2}$ proteins on the donor side of PS II [10], to chloroplasts, the activity of which was inhibited by the most active compound 6 (up to $30 \%$ of 
the control), caused practically complete PET restoration already at addition of 3-fold DPC concentration with regard to the applied concentration of compound $\mathbf{6}$. Therefore it can be concluded that the site of action of the studied 1-[(2-nitrophenyl)carbamoyl]naphthalen-2-yl alkylcarbamates is situated mainly on the donor side of PS II. The site of action situated on the donor side of PS II was found also for 2-alkylthio-6-R-benzothiazoles ( $\mathrm{R}=6$-formamido-, 6-acetamido-, and 6-benzoylamino-) [35], anilides of 2-alkylpyridine-4-carboxylic acids [36], cationic surfactants [37,38] acting in the intermediates $\mathrm{Z}^{\circ} / \mathrm{D}^{\bullet}$ and 2-alkylsulphanyl4-pyridinecarbothioamides acting in the $\mathrm{D}^{\bullet}$ intermediate [39].

\section{EXPERIMENTAL}

\section{General}

All reagents were purchased from Aldrich (Sigma-Aldrich, St. Louis, MO, USA) and Alfa (Alfa-Aesar, Ward Hill, Massachusetts, USA). TLC experiments were performed on alumina-backed silica gel 60 F254 plates (Merck, Darmstadt, Germany). The plates were illuminated under UV $(254 \mathrm{~nm})$ and evaluated in iodine vapour. The melting points were determined on a Kofler hot-plate apparatus HMK (Franz Kustner Nacht KG, Dresden, Germany) and are uncorrected. Infrared (IR) spectra were recorded on a Smart MIRacle ${ }^{\mathrm{TM}}$ ATR ZnSe for Nicolet ${ }^{\mathrm{TM}}$ Impact 410 FT-IR spectrometer (Thermo Scientific, West Palm Beach, FL, USA). The spectra were obtained by accumulation of 256 scans with $2 \mathrm{~cm}^{-1}$ resolution in the region of $4000-650 \mathrm{~cm}^{-1}$. All ${ }^{1} \mathrm{H}$ - and ${ }^{13} \mathrm{C}-\mathrm{NMR}$ spectra were recorded on a JEOL ECZR $400 \mathrm{MHz}$ NMR spectrometer $\left(400 \mathrm{MHz}\right.$ for ${ }^{1} \mathrm{H}$ and $100 \mathrm{MHz}$ for ${ }^{13} \mathrm{C}$, JEOL, Tokyo, Japan) in DMSO- $d_{6} \cdot{ }^{1} \mathrm{H}$ and ${ }^{13} \mathrm{C}$ chemical shifts $(\delta)$ are reported in ppm. Highresolution mass spectra were measured using a high-performance liquid chromatograph Dionex UltiMate ${ }^{\circledR} 3000$ (Thermo Scientific) coupled with a LTQ Orbitrap XL ${ }^{\text {TM }}$ Hybrid Ion Trap-Orbitrap Fourier Transform Mass Spectrometer (Thermo Scientific) with injection into HESI II in the positive mode. The lipophilicity $(\log P)$ of the final compounds, the surface tension and the molar volume of R substituents were predicted using ACD/Percepta ver. 2012 (Advanced Chemistry Development, Inc., Toronto, ON, Canada).

\section{Synthesis}

The synthetic pathway and the characterization of $N$-(2-nitrophenyl)-2-hydroxynaphthalene-1carboxamide (1) were described by Gonec et al. [18]. The characterizations of target 1-[(2-nitrophenyl)carbamoyl]naphthalen-2-yl alkylcarbamates 2-9 were published recently [30], nevertheless, for the complexity of the studies, the analytical data of individual discussed compounds are mentioned below.

General procedure for synthesis of alkylcarbamates 2-9: $\quad N$-(2-nitrophenyl)-2hydroxynaphthalene-1-carboxamide $(\mathbf{1}, 1.0 \mathrm{mmol})$ and triethylamine $(1.1 \mathrm{mmol})$ were suspended in dry acetonitrile $(10 \mathrm{~mL})$. The solution of the appropriate alkyl isocyanate $(1.2 \mathrm{mmol})$ in acetonitrile $(5 \mathrm{~mL})$ was added in four portions within $2 \mathrm{~h}$, and the reacting mixture was stirred for $24 \mathrm{~h}$ at ambient temperature. The solvent was evaporated under reduced pressure, and the solid residue was washed with methanol and ethyl acetate to give pure product. Studied compounds 2-9 are presented in Table 1.

1-[(2-Nitrophenyl)carbamoyl]naphthalen-2-yl ethylcarbamate (2). Yield 40\%; Mp 157-159 ${ }^{\circ} \mathrm{C}$; IR $\left(\mathrm{cm}^{-1}\right): 3320,3216,2963,2917,2843,1743,1705,1656,1645,1608,1580,1532,1504$, $1462,1432,1357,1341,1294,1270,1250,1216,1199,1162,1144,1079,1034,993,822$, 791, 779, 732, 667; ${ }^{1} \mathrm{H}-\mathrm{NMR}\left(\mathrm{DMSO}-d_{6}\right) \delta: 10.94(\mathrm{~s}, 1 \mathrm{H}), 8.07(\mathrm{~d}, J=9.1 \mathrm{~Hz}, 1 \mathrm{H}), 8.01-8.05$ (m, 3H), 7.71-7.80 (m, 3H), 7.65 (ddd, $J=8.2 \mathrm{~Hz}, 6.9 \mathrm{~Hz}, 1.4 \mathrm{~Hz}, 1 \mathrm{H}), 7.59$ (ddd, $J=8.2 \mathrm{~Hz}$, $6.9 \mathrm{~Hz}, 1.4 \mathrm{~Hz}, 1 \mathrm{H}), 7.41-7.48(\mathrm{~m}, 2 \mathrm{H}), 3.04-3.11(\mathrm{~m}, 2 \mathrm{H}), 1.03(\mathrm{t}, J=7.1 \mathrm{~Hz}, 3 \mathrm{H})$; ${ }^{13} \mathrm{C}-\mathrm{NMR}\left(\mathrm{DMSO}-d_{6}\right.$ ), $\delta: 164.12,153.71,145.56,142.98,133.89,130.62,130.51,130.33$, 
$130.26,128.10,127.42,125.91,125.82,125.70,124.96,124.90,124.43,122.62,35.39,14.75$; HR-MS: for $\mathrm{C}_{20} \mathrm{H}_{16} \mathrm{O}_{5} \mathrm{~N}_{3}[\mathrm{M}+\mathrm{H}]^{+}$calculated 378.10845 , found $378.10934 \mathrm{~m} / \mathrm{z}$.

1-[(2-Nitrophenyl)carbamoyl]naphthalen-2-yl propylcarbamate (3). Yield 75\%; Mp $153-155^{\circ} \mathrm{C}$; IR $\left(\mathrm{cm}^{-1}\right): 3298,3223,2960,2930,2873,1727,1717,1662,1589,1537,1520,1505,1488$, 1463, 1440, 1353, 1285, 1257, 1224, 1146, 1106, 1051, 996, 981, 914, 865, 818, 779, 731, 666; ${ }^{1} \mathrm{H}-\mathrm{NMR}\left(\mathrm{DMSO}-d_{6}\right) \delta: 10.93(\mathrm{~s}, 1 \mathrm{H}), 8.07(\mathrm{~d}, J=9.1 \mathrm{~Hz}, 1 \mathrm{H}), 8.01-8.05(\mathrm{~m}, 3 \mathrm{H})$, $7.72-7.82(\mathrm{~m}, 3 \mathrm{H}), 7.65(\mathrm{ddd}, J=8.2 \mathrm{~Hz}, 6.9 \mathrm{~Hz}, 1.4 \mathrm{~Hz}, 1 \mathrm{H}), 7.59$ (ddd, $J=8.2 \mathrm{~Hz}, 6.9 \mathrm{~Hz}$, $1.4 \mathrm{~Hz}, 1 \mathrm{H}), 7.41-7.48(\mathrm{~m}, 2 \mathrm{H}), 3.00(\mathrm{q}, J=6.5 \mathrm{~Hz}, 2 \mathrm{H}), 1.42(\mathrm{sx}, J=7.1 \mathrm{~Hz}, 2 \mathrm{H}), 0.80(\mathrm{t}$, $J=7.3 \mathrm{~Hz}, 3 \mathrm{H}$ ); ${ }^{13} \mathrm{C}-\mathrm{NMR}$ (DMSO- $\left.d_{6}\right), \delta: 164.14,153.94,145.61,142.89,133.91,130.69$, $130.53,130.33,130.33,128.11,127.43,125.93,125.79,125.72,125.64,124.91,124.46$, 122.62, 42.29, 22.37, 11.10; HR-MS: for $\mathrm{C}_{21} \mathrm{H}_{18} \mathrm{O}_{5} \mathrm{~N}_{3}[\mathrm{M}+\mathrm{H}]^{+}$calculated 392.12410, found $392.12521 \mathrm{~m} / \mathrm{z}$.

1-[(2-Nitrophenyl)carbamoyl]naphthalen-2-yl isoproylcarbamate (4). Yield 69\%; Mp 172-176 ${ }^{\circ} \mathrm{C}$; IR $\left(\mathrm{cm}^{-1}\right)$ : 3355, 3320, 2974, 1738, 1665, 1586, 1532, 1505, 1489, 1440, 1362, 1245, 1213, $1173,1149,1056,1018,953,924,826,778,763,732 ;{ }^{1} \mathrm{H}-\mathrm{NMR}$ (DMSO- $\left.d_{6}\right) \delta: 10.93(\mathrm{~s}, 1 \mathrm{H})$, $8.07(\mathrm{~d}, J=9.1 \mathrm{~Hz}, 1 \mathrm{H}), 8.01-8.05(\mathrm{~m}, 3 \mathrm{H}), 7.75-7.80(\mathrm{~m}, 3 \mathrm{H}), 7.66$ (ddd, $J=8.2 \mathrm{~Hz}$, $6.9 \mathrm{~Hz}, 1.4 \mathrm{~Hz}, 1 \mathrm{H}), 7.59$ (ddd, $J=8.2 \mathrm{~Hz}, 6.9 \mathrm{~Hz}, 1.4 \mathrm{~Hz}, 1 \mathrm{H}), 7.46(\mathrm{td}, J=8.2 \mathrm{~Hz}, 1.4 \mathrm{~Hz}$, $1 \mathrm{H}), 7.42(\mathrm{~d}, J=9.1 \mathrm{~Hz}, 1 \mathrm{H}), 3.65(\mathrm{sx}, J=6.4 \mathrm{~Hz}, 2 \mathrm{H}), 1.07(\mathrm{~d}, J=6.4 \mathrm{~Hz}, 6 \mathrm{H}) ;{ }^{13} \mathrm{C}-\mathrm{NMR}$ $\left(\mathrm{DMSO}-d_{6}\right), \delta: 164.18,153.10,145.61,142.94,133.92,130.69,130.54,130.37,130.33$, $128.14,127.46,125.96,125.85,125.80,125.72,124.94,124.46,122.71,42.86,22.32$; HR-MS: for $\mathrm{C}_{21} \mathrm{H}_{18} \mathrm{O}_{5} \mathrm{~N}_{3}[\mathrm{M}+\mathrm{H}]^{+}$calculated 394.13975 , found $394.14058 \mathrm{~m} / z$.

1-[(2-Nitrophenyl)carbamoyl]naphthalen-2-yl butylcarbamate (5). Yield 82\%; Mp 171-174 ${ }^{\circ} \mathrm{C}$; IR $\left(\mathrm{cm}^{-1}\right): 3293,3222,2957,2873,1724,1661,1589,1549,1532,1520,1505,1471,1463$, 1439, 1350, 1279, 1257, 1227, 1145, 1109, 1006, 914, 865, 818, 779, 769, 731, 680, 667; ${ }^{1} \mathrm{H}-\mathrm{NMR}\left(\mathrm{DMSO}-d_{6}\right) \delta$ : $10.92(\mathrm{~s}, 1 \mathrm{H}), 8.07(\mathrm{~d}, J=9.1 \mathrm{~Hz}, 1 \mathrm{H}), 8.01-8.05(\mathrm{~m}, 3 \mathrm{H}), 7.73-7.80$ $(\mathrm{m}, 3 \mathrm{H}), 7.65$ (ddd, $J=8.2 \mathrm{~Hz}, 6.9 \mathrm{~Hz}, 1.4 \mathrm{~Hz}, 1 \mathrm{H}), 7.58$ (ddd, $J=8.2 \mathrm{~Hz}, 6.9 \mathrm{~Hz}, 1.4 \mathrm{~Hz}$, $1 \mathrm{H}), 7.45(\mathrm{td}, J=8.2 \mathrm{~Hz}, 1.4 \mathrm{~Hz}, 1 \mathrm{H}), 7.38(\mathrm{~d}, J=9.1 \mathrm{~Hz}, 1 \mathrm{H}), 3.03(\mathrm{q}, J=6.2 \mathrm{~Hz}, 2 \mathrm{H}), 1.38$ (qi, $J=7.0 \mathrm{~Hz}, 2 \mathrm{H}), 1.23(\mathrm{sx}, J=7.0 \mathrm{~Hz}, 2 \mathrm{H}), 0.81(\mathrm{t}, J=7.1 \mathrm{~Hz}, 3 \mathrm{H}) ;{ }^{13} \mathrm{C}-\mathrm{NMR}$ (DMSO- $d_{6}$ ), $\delta: 164.13,153.91,145.58,142.77,133.91,130.74,130.52,130.32,130.31,128.10,127.41$, 125.91, 125.74, 125.73, 125.56, 124.91, 124.44, 122.59, 40.18, 31.23, 19.27, 13.58; HR-MS: for $\mathrm{C}_{22} \mathrm{H}_{20} \mathrm{O}_{5} \mathrm{~N}_{3}[\mathrm{M}+\mathrm{H}]^{+}$calculated 406.13975 , found $406.14081 \mathrm{~m} / \mathrm{z}$.

1-[(2-Nitrophenyl)carbamoyl]naphthalen-2-yl pentylcarbamate (6). Yield 70\%; Mp 141-143 ${ }^{\circ} \mathrm{C}$; IR $\left(\mathrm{cm}^{-1}\right)$ : 3298, 3226, 2935, 2874, 1723, 1667, 1588, 1548, 1532, 1519, 1505, 1485, 1475, 1436, 1347, 1322, 1284, 1253, 1226, 1142, 1108, 1037, 1025, 996, 913, 866, 819, 778, 767, 730, 680, 660; ${ }^{1} \mathrm{H}-\mathrm{NMR}$ (DMSO-d $)_{6} \delta: 10.93(\mathrm{~s}, 1 \mathrm{H}), 8.07(\mathrm{~d}, J=9.1 \mathrm{~Hz}, 1 \mathrm{H}), 8.01-8.05(\mathrm{~m}, 3 \mathrm{H})$, $7.75-7.81(\mathrm{~m}, 3 \mathrm{H}), 7.65(\mathrm{ddd}, J=8.2 \mathrm{~Hz}, 6.9 \mathrm{~Hz}, 1.4 \mathrm{~Hz}, 1 \mathrm{H}), 7.58$ (ddd, $J=8.2 \mathrm{~Hz}, 6.9 \mathrm{~Hz}$, $1.4 \mathrm{~Hz}, 1 \mathrm{H}), 7.45(\mathrm{td}, J=8.2 \mathrm{~Hz}, 1.4 \mathrm{~Hz}, 1 \mathrm{H}), 7.41(\mathrm{~d}, J=9.1 \mathrm{~Hz}, 1 \mathrm{H}), 3.02(\mathrm{q}, J=6.4 \mathrm{~Hz}, 2 \mathrm{H})$, 1.40 (qi, $J=7.0 \mathrm{~Hz}, 2 \mathrm{H}), 1.09-1.33(\mathrm{~m}, 4 \mathrm{H}), 0.82(\mathrm{t}, J=6.2 \mathrm{~Hz}, 3 \mathrm{H}) ;{ }^{13} \mathrm{C}-\mathrm{NMR}$ (DMSO- $\left.d_{6}\right), \delta$ : 164.12, 153.89, 145.58, 142.80, 133.88, 130.72, 130.51, 130.31, 130.30, 128.10, 127.42, 125.91, 125.74, 125.72, 125.58, 124.91, 124.44, 122.61, 40.47, 28.77, 28.29, 21.76, 13.83; HR-MS: for $\mathrm{C}_{23} \mathrm{H}_{22} \mathrm{O}_{5} \mathrm{~N}_{3}[\mathrm{M}+\mathrm{H}]^{+}$calculated 420.15540 , found $420.15643 \mathrm{~m} / z$.

1-[(2-Nitrophenyl)carbamoyl]naphthalen-2-yl hexylcarbamate (7). Yield 58\%; Mp 122-123 ${ }^{\circ} \mathrm{C}$; IR $\left(\mathrm{cm}^{-1}\right)$ : 3332, 3272, 2929, 2868, 1709, 1665, 1609, 1589, 1541, 1514, 1472, 1443, 1352, $1295,1250,1215,1205,1158,1148,1113,1046,993,978,911,863,825,779,761,738,697$, 672; ${ }^{1} \mathrm{H}-\mathrm{NMR}\left(\mathrm{DMSO}-d_{6}\right) \delta: 10.93(\mathrm{~s}, 1 \mathrm{H}), 8.07(\mathrm{~d}, J=9.1 \mathrm{~Hz}, 1 \mathrm{H}), 8.01-8.05(\mathrm{~m}, 3 \mathrm{H})$, $7.75-7.81(\mathrm{~m}, 3 \mathrm{H}), 7.65(\mathrm{ddd}, J=8.2 \mathrm{~Hz}, 6.9 \mathrm{~Hz}, 1.4 \mathrm{~Hz}, 1 \mathrm{H}), 7.58(\mathrm{ddd}, J=8.2 \mathrm{~Hz}, 6.9 \mathrm{~Hz}$, $1.4 \mathrm{~Hz}, 1 \mathrm{H}), 7.45(\mathrm{td}, J=8.2 \mathrm{~Hz}, 1.4 \mathrm{~Hz}, 1 \mathrm{H}), 7.41(\mathrm{~d}, J=9.1 \mathrm{~Hz}, 1 \mathrm{H}), 3.02(\mathrm{q}, J=6.0 \mathrm{~Hz}$, $2 \mathrm{H}), 1.38$ (qi, $J=6.4 \mathrm{~Hz}, 2 \mathrm{H}), 1.18-1.25(\mathrm{~m}, 6 \mathrm{H}), 0.83(\mathrm{t}, J=6.6 \mathrm{~Hz}, 3 \mathrm{H}) ;{ }^{13} \mathrm{C}-\mathrm{NMR}$ 
(DMSO- $\left.d_{6}\right), \delta: 164.65,154.44,146.08,143.25,134.42,131.24,131.04,130.83,130.82,128.61$, 127.94, 126.44, 126.23, 126.23, 126.06, 125.42, 124.94, 123.10, 41.03, 31.42, 29.56, 26.28, 22.49, 14.38; HR-MS: for $\mathrm{C}_{24} \mathrm{H}_{24} \mathrm{O}_{5} \mathrm{~N}_{3}[\mathrm{M}+\mathrm{H}]^{+}$calculated 434.17105 , found $434.17236 \mathrm{~m} / \mathrm{z}$.

1-[(2-Nitrophenyl)carbamoyl]naphthalen-2-yl heptylcarbamate (8). Yield 46\%; Mp 101-102 ${ }^{\circ} \mathrm{C}$; IR $\left(\mathrm{cm}^{-1}\right): 3333,3265,2957,2925,2852,1709,1665,1652,1609,1588,1541,1511,1472$, $1464,1441,1350,1294,1250,1215,1205,1148,1045,979,911,824,779,755,737,696$, 667; ${ }^{1} \mathrm{H}-\mathrm{NMR}\left(\mathrm{DMSO}-d_{6}\right) \delta: 10.93(\mathrm{~s}, 1 \mathrm{H}), 8.07(\mathrm{~d}, J=9.1 \mathrm{~Hz}, 1 \mathrm{H}), 8.01-8.05(\mathrm{~m}, 3 \mathrm{H})$, $7.75-7.81(\mathrm{~m}, 3 \mathrm{H}), 7.65(\mathrm{ddd}, J=8.2 \mathrm{~Hz}, 6.9 \mathrm{~Hz}, 1.4 \mathrm{~Hz}, 1 \mathrm{H}), 7.58(\mathrm{ddd}, J=8.2 \mathrm{~Hz}, 6.9 \mathrm{~Hz}$, $1.4 \mathrm{~Hz}, 1 \mathrm{H}), 7.45(\mathrm{td}, J=8.2 \mathrm{~Hz}, 1.4 \mathrm{~Hz}, 1 \mathrm{H}), 7.41(\mathrm{~d}, J=9.1 \mathrm{~Hz}, 1 \mathrm{H}), 3.02(\mathrm{q}, J=6.3 \mathrm{~Hz}$, $2 \mathrm{H}), 1.39$ (qi, $J=6.4 \mathrm{~Hz}, 2 \mathrm{H}), 1.17-1.28(\mathrm{~m}, 8 \mathrm{H}), 0.85(\mathrm{t}, J=6.6 \mathrm{~Hz}, 3 \mathrm{H}) ;{ }^{13} \mathrm{C}-\mathrm{NMR}$ (DMSO- $\left.d_{6}\right), \delta: 164.12,153.89,145.58,142.77,133.88,130.74,130.53,130.31,130.31$, $128.10,127.42$, 125.91, 125.73, 125.72, 125.58, 124.90, 124.44, 122.61, 40.50, 31.16, 29.11, 28.36, 26.07, 22.04, 13.93; HR-MS: for $\mathrm{C}_{25} \mathrm{H}_{26} \mathrm{O}_{5} \mathrm{~N}_{3}[\mathrm{M}+\mathrm{H}]^{+}$calculated 448.18670, found $448.18848 \mathrm{~m} / \mathrm{z}$.

1-[(2-Nitrophenyl)carbamoyl]naphthalen-2-yl octylcarbamate (9). Yield 37\%; Mp 92-94 ${ }^{\circ} \mathrm{C}$; IR $\left(\mathrm{cm}^{-1}\right): 3315,3230,2924,2850,1704,1653,1589,1528,1508,1485,1463,1435,1360$, 1293, 1271, 1251, 1219, 915, 834, 780, 759, 736, 701, 667; ${ }^{1} \mathrm{H}-\mathrm{NMR}$ (DMSO- $d_{6}$ ) $\delta: 10.93$ (s, $1 \mathrm{H}), 8.07(\mathrm{~d}, J=9.1 \mathrm{~Hz}, 1 \mathrm{H}), 8.01-8.05(\mathrm{~m}, 3 \mathrm{H}), 7.75-7.81(\mathrm{~m}, 3 \mathrm{H}), 7.65(\mathrm{ddd}, J=8.2 \mathrm{~Hz}$, $6.9 \mathrm{~Hz}, 1.4 \mathrm{~Hz}, 1 \mathrm{H}), 7.59$ (ddd, $J=8.2 \mathrm{~Hz}, 6.9 \mathrm{~Hz}, 1.4 \mathrm{~Hz}, 1 \mathrm{H}), 7.46$ (td, $J=8.2 \mathrm{~Hz}, 1.4 \mathrm{~Hz}$, $1 \mathrm{H}), 7.41(\mathrm{~d}, J=9.1 \mathrm{~Hz}, 1 \mathrm{H}), 3.03(\mathrm{q}, J=5.5 \mathrm{~Hz}, 2 \mathrm{H}), 1.39$ (qi, $J=6.0 \mathrm{~Hz}, 2 \mathrm{H}), 1.18-1.29$ $(\mathrm{m}, 10 \mathrm{H}), 0.86(\mathrm{t}, J=6.4 \mathrm{~Hz}, 3 \mathrm{H}) ;{ }^{13} \mathrm{C}-\mathrm{NMR}$ (DMSO-d $), \delta: 164.12,153.89,145.58,142.79$, $133.86,130.72$, 130.51, 130.32, 130.31, 128.10, 127.42, 125.91, 125.75, 125.72, 125.58, 124.90, 124.44, 122.59, 40.50, 31.22, 29.09, 28.67, 28.59, 26.12, 22.07, 13.95; HR-MS: for $\mathrm{C}_{26} \mathrm{H}_{28} \mathrm{O}_{5} \mathrm{~N}_{3}[\mathrm{M}+\mathrm{H}]^{+}$calculated 462.20235 , found $462.20410 \mathrm{~m} / \mathrm{z}$.

\section{Study of photosynthetic electron transport (PET) inhibition in spinach chloroplasts}

Chloroplasts were prepared from spinach (Spinacia oleracea L.) according to Masarovicova and Kralova [40]. The inhibition of photosynthetic electron transport (PET) in spinach chloroplasts was determined spectrophotometrically (Genesys 6, Thermo Scientific), using the artificial electron acceptor 2,6-dichlorophenol-indophenol (DCPIP) according to Kralova et al. [41], and the rate of photosynthetic electron transport was monitored as a photoreduction of DCPIP. The measurements were carried out in phosphate buffer $(0.02 \mathrm{~mol} / \mathrm{L}, \mathrm{pH} 7.2)$ containing sucrose $(0.4 \mathrm{~mol} / \mathrm{L}), \mathrm{MgCl}_{2}(0.005 \mathrm{~mol} / \mathrm{L})$ and $\mathrm{NaCl}$ $(0.015 \mathrm{~mol} / \mathrm{L})$. The chlorophyll content was $30 \mathrm{mg} / \mathrm{L}$ in these experiments, and the samples were irradiated $\left(\sim 100 \mathrm{~W} / \mathrm{m}^{2}\right.$ with $10 \mathrm{~cm}$ distance) with a halogen lamp $(250 \mathrm{~W})$ using a $4 \mathrm{~cm}$ water filter to prevent warming of the samples (suspension temperature $\sim 4{ }^{\circ} \mathrm{C}$ ). The studied compounds were dissolved in DMSO due to their limited water solubility. The applied DMSO concentration (up to 4\%) did not affect the photochemical activity in spinach chloroplasts. The inhibitory efficiency of the studied compounds was expressed by $\mathrm{IC}_{50}$ values, i.e. by molar concentration of the compounds causing a $50 \%$ decrease in the oxygen evolution rate relative to the untreated control. The comparable $\mathrm{IC}_{50}$ value for the selective herbicide 3-(3,4-dichlorophenyl)-1,1-dimethylurea, DCMU (Diuron ${ }^{\circledR}$ ), was about $0.002 \mathrm{mmol} / \mathrm{L}$. The results are summarized in Table 1.

\section{ACKNOWLEDGEMENTS}

This study was supported by IGA VFU Brno 320/2015/FaF and by the Slovak Research and Development Agency (Grant No. APVV-0516-12). The HPLC/HRMS system forms a part of the National Infrastructure CzeCOS (LM2015061); Michal Oravec was supported by the National Sustainability Program (NPU I; Grant No. LO1415 POLYMAT). 


\section{REFERENCES}

1. Steinhilber, D.; Schubert-Zsilavecz, M.; Roth, H.J. Medizinische Chemie: Targets, Arzneistoffe, Chemische Biologie. Deutscher Apotheker Verlag, Stutgart, Germany; 2010.

2. US Environmental Protection Agency - Pesticide Registration: Pesticide Data Submitters List (PDSL), 2016. Available online: https://www.epa.gov/sites/production/files/201604/documents/dslchem_0.pdf (accessed on 25 September 2016).

3. Pattabiraman, V. R. Bode, J. W. Rethinking amide bond synthesis. Nature 2011, 480, 471-479.

4. Ghosh, A.K.; Brindisi, M. Organic carbamates in drug design and medicinal chemistry. J. Med. Chem. 2015, 58, 2895-2940.

5. Good, N.E. Inhibitors of the Hill reaction. Plant Physiol. 1961, 36, 788-803.

6. Draber, W.; Tietjen, K.; Kluth, J.F.; Trebst, A. Herbicides in photosynthesis research. Angew. Chem. 1991, 3, 1621-1633.

7. Tischer, W.; Strotmann, H. Relationship between inhibitor binding by chloroplasts and inhibition of photosynthetic electron-transport. Biochim. Biophys. Acta 1977, 460, 113-125.

8. Trebst, A.; Draber, W. Structure activity correlations of recent herbicides in photosynthetic reactions. In: Advances in Pesticide Science; Greissbuehler, H., Ed.; Pergamon Press: Oxford, 1979; pp. 223-234.

9. Bowyer, J.R.; Camilleri, P.; Vermaas, W.F.J. Photosystem II and its interaction with herbicides. In: Herbicides, Topics in Photosynthesis, Baker, N.R.; Percival, M.P., Eds.; Elsevier Science B.V: Amsterdam, 1991; Vol. 10, pp. 27-85.

10. Izawa, S. Acceptors and donors for chloroplast electron transport. In Methods in Enzymology, Vol. 69, Part C, Colowick, P., Kaplan, N.O., Eds.; Academic Press: New York - London, UK, 1980; pp. 413-434.

11. Kralova, K.; Sersen, F.; Cizmarik, J. Inhibitory effect of piperidinoethylesters of alkoxyphenylcarbamic acids on photosynthesis. Gen. Physiol. Biophys. 1992, 11, 261-267.

12. Kralova, K.; Sersen, F.; Kubicova, L.; Waisser, K. Inhibitory effects of substituted benzanilides on photosynthetic electron transport in spinach chloroplasts. Chem. Pap. 1999, 53, 328-331.

13. Kralova, K.; Sersen, F.; Kubicova, L.; Waisser, K. Inhibition of photosynthetic electron transport in spinach chloroplasts by 3- and 4-halogeno substituted benzanilides and thiobenzanilides. J. Trace Microprobe Technol. 2000, 18, 251-256.

14. Otevrel, J.; Mandelova, Z.; Pesko, M.; Guo, J.; Kralova, K.; Sersen, F.; Vejsova, M.; Kalinowski, D.; Kovacevic, Z.; Coffey, A.; Csollei, J.; Richardson, D.R.; Jampilek, J. Investigating the spectrum of biological activity of ring-substituted salicylanilides and carbamoylphenylcarbamates. Molecules 2010, 15, 8122-8142.

15. Imramovsky, A.; Pesko, M.; Kralova, K.; Vejsova, M.; Stolarikova, J.; Vinsova, J.; Jampilek, J. Investigating spectrum of biological activity of 4- and 5-chloro-2-hydroxyN-[2-(arylamino)-1-alkyl-2-oxoethyl]benzamides. Molecules 2011, 16, 2414-2430.

16. Imramovsky, A.; Pesko, M.; Monreal-Ferriz, J.; Kralova, K.; Vinsova, J.; Jampilek, J. Photosynthesis-inhibiting efficiency of 4-chloro-2-(chlorophenylcarbamoyl)phenyl alkylcarbamates. Bioorg. Med. Chem. Lett. 2011, 21, 4564-4567.

17. Kos, J.; Zadrazilova, I.; Pesko, M.; Keltosova, S.; Tengler, J.; Gonec, T.; Bobal, P.; Kauerova, T.; Oravec, M.; Kollar, P.; Cizek, A.; Kralova, K.; Jampilek, J. Antibacterial and herbicidal activity of ring-substituted 3-hydroxynaphthalene-2-carboxanilides. Molecules 2013, 18, 7977-7997.

18. Gonec, T.; Kos, J.; Zadrazilova, I.; Pesko, M.; Govender, R.; Keltosova, S.; Chambel, B.; Pereira, D.; Kollar, P.; Imramovsky, A.; O’Mahony, J.; Coffey, A.; Cizek, A.; Kralova, K.; Jampilek, J. Antibacterial and herbicidal activity of ring-substituted 2-hydroxynaphthalene-1-carboxanilides. Molecules 2013, 18, 9397-9419. 
19. Gonec, T.; Kos, J.; Zadrazilova, I.; Pesko, M.; Keltosova, S.; Tengler, J.; Bobal, P.; Kollar, P.; Cizek, A.; Kralova, K.; Jampilek, J. Antimycobacterial and herbicidal activity of ringsubstituted 1-hydroxynaphthalene-2-carboxanilides. Bioorg. Med. Chem. 2013, 21, 6531-6541.

20. Gonec, T.; Zadrazilova, I.; Nevin, E.; Kauerova, T.; Pesko, M.; Kos, J.; Oravec, M.; Kollar, P.; Coffey, A.; O’Mahony, J.; Cizek, A.; Kralova, K.; Jampilek, J. Synthesis and biological evaluation of $N$-alkoxyphenyl-3-hydroxynaphthalene-2-carboxanilides. Molecules 2015, 20, 9767-9787.

21. Kralova, K.; Perina, M.; Waisser, K.; Jampilek, J. Structure-activity relationships of N-benzyl-salicylamides for inhibition of photosynthetic electron transport. Med. Chem. 2015, 11, 156-164.

22. Williamson, R.L.; Metcalf, R.L. Salicylanilides: A new group of active uncouplers of oxidative phosphorylation. Science 1967, 158, 1694-1695.

23. Renger, G. The action of 5-chloro-3-tert-butyl-2'-chloro-4'-nitro-salicylanilide and $\alpha, \alpha$-bis(hexafluoroacetonyl)aceton on the water-splitting enzyme system $\mathrm{Y}$ in spinach chloroplasts. FEBS Lett. 1975, 52, 30-32.

24. Black, C.C. Photosynthetic phosphorylation and associated reactions in the presence of a new group of uncouplers: Salicylanilides. Biochim. Biophys. Acta 1968, 162, 294-296.

25. Jampilek, J.; Dolezal, M.; Kunes, J.; Buchta, V.; Silva, L.; Kralova, K. Quinaldine derivatives: Preparation and biological activity. Med. Chem. 2005, 1, 591-599.

26. Musiol, R.; Jampilek, J.; Kralova, K.; Richardson, D.R.; Kalinowski, D.; Podeszwa, B.; Finster, J.; Niedbala, H.; Palka, A.; Polanski, J. Investigating biological activity spectrum for novel quinoline analogues. Bioorg. Med. Chem. 2007, 15, 1280-1288.

27. Musiol, R.; Tabak, D.; Niedbala, H.; Podeszwa, B.; Jampilek, J.; Kralova, K.; Dohnal, J.; Finster, J.; Mencel, A.; Polanski, J. Investigating biological activity spectrum for novel quinoline analogues 2: Hydroxyquinolinecarboxamides with photosynthesis inhibiting activity. Bioorg. Med. Chem. 2008, 16, 4490-4499.

28. Jampilek, J.; Kralova, K.; Pesko, M.; Kos, J. Ring-substituted 8-hydroxyquinoline-2carboxanilides as photosystem II inhibitors. Bioorg. Med. Chem. Lett. 2016, 26, 3862-3865.

29. Zadrazilova, I.; Pospisilova, S.; Masarikova, M.; Imramovsky, A.; Monreal-Ferriz, J.; Vinsova, J.; Cizek, A.; Jampilek, J. Salicylanilide carbamates: Promising antibacterial agents with high in vitro activity against methicillin-resistant Staphylococcus aureus. Eur. J. Pharm. Sci. 2015, 77, 197-207.

30. Gonec, T.; Pospisilova, S.; Holanova, L.; Stranik, J.; Cernikova, A.; Pudelkova, V.; Kos, J.; Oravec, M.; Kollar, P.; Cizek, A.; Jampilek, J. Synthesis and antimicrobial evaluation of 1-[(2-substituted phenyl)carbamoyl]naphthalen-2-yl carbamates. Molecules 2016, 21, 1189.

31. Gonec, T.; Stranik, J.; Pesko, M.; Kos, J.; Oravec, M.; Kralova, K.; Jampilek, J. Preparation and photosynthesis-inhibiting activity of 1-[(2-chlorophenyl)carbamoyl]naphthalen-2-yl alkylcarbamates. ECSOC-19, 2015, November 1-30, b006, http://sciforum.net/conference/ 80/paper/3079.

32. Balgavy, P.; Devinsky, F. Cut-off effects in biological activities of surfactants. Adv. Colloid Interfac. 1996, 66, 23-63.

33. Przestalski, S.; Sarapuk, J.; Kleszczynska, H.; Gabrielska, J.; Hladyszowski, J.; Trela, Z.; Kuczera, J. Influence of amphiphilic compounds on membranes. Acta Biochim. Pol. 2000, 47, 627-638.

34. Sarapuk, J.; Kubica, K. Cut-off phenomenon. Cell. Mol. Biol. Lett. 1998, 5, 261-269.

35. Kralova, K.; Sersen, F.; Sidoova, E. Effects of 2-alkylthio-6-aminobenzothiazoles and their 6-N-substituted derivatives on photosynthesis inhibition in Chlorella vulgaris and spinach chloroplasts. Gen. Phys. Biophys. 1993, 12, 421-427. 
36. Kralova, K.; Sersen, F.; Miletin, M.; Hartl, J. Inhibition of photosynthetic electron transport by some anilides of 2-alkylpyridine-4-carboxylic acids in spinach chloroplasts. Chem. Pap. 1998, 52, 52-58.

37. Kralova, K.; Sersen, F. Long chain bisquaternary ammonium salts - effective inhibitors of photosynthesis. Tenside Surfact. Det. 1994, 31, 192-194.

38. Kralova, K.; Sersen, F.; Devinsky, F.; Lacko, I. Photosynthesis-inhibiting effects of cationic biodegradable gemini surfactants. Tenside Surfact. Det. 2010, 47, $288-293$.

39. Kralova, K.; Sersen, F.; Klimesova, V.; Waisser, K. 2-Alkylsulphanyl-4-pyridinecarbothioamides-inhibitors of oxygen evolution in freshwater alga Chlorella vulgaris. Chem. Pap. 2011, 65, 909-912.

40. Masarovicova, E.; Kralova, K. Approaches to measuring plant photosynthesis activity. In Handbook of Photosynthesis, 2nd ed.; Pessarakli, M., Ed.; Taylor \& Francis Group: Boca Raton, FL, USA, 2005; pp. 617-656.

41. Kralova, K.; Sersen, F.; Sidoova, E. Photosynthesis inhibition produced by 2-alkylthio6-R-benzothiazoles. Chem. Pap. 1992, 46, 348-350. 